\title{
Penerapan metode inkuiri untuk meningkatkan kemampuan komunikasi matematis siswa kelas VIII B SMP Negeri 2 Sampung
}

\author{
Wilis Sindhu Kiswara, Subanji* \\ Universitas Negeri Malang, Jl. Semarang No. 5 Malang, Jawa Timur, Indonesia \\ *Penulis korespondensi, Surel: subanji.fmipa@um.ac.id
}

Paper received: 01-12-2021; revised: 15-12-2021; accepted: 31-12-2021

\begin{abstract}
Abstrak
Komunikasi merupakan salah satu standar pembelajaran yang harus dikuasai oleh siswa. Tujuan penelitian ini adalah untuk mendeskripsikan penerapan metode inkuiri yang dapat meningkatkan komunikasi matematis siswa kelas VIII B SMP Negeri 2 Sampung. Penelitian merupakan penelitian tindakan kelas yang terdiri dari 2 siklus, masing-masing siklus terdiri dari 2 pertemuan. Langkahlangkah Inkuiri yang dapat meningkatkan kemampuan komunikasi matematis siswa meliputi: mengkondisikan berpikir dengan memberikan masalah, guru mendorong siswa untuk menemukan (inquiri), guru memberikan scaffolding, guru meminta mereka untuk menguji gagasan melalui kelompok, dan guru mengembangkan pengetahuan siswa untuk berkomunikasi matematis. Kemampuan komunikasi matematis siswa berdasarkan hasil tes meningkat dari 66,6 persen pada siklus 1 menjadi 77,7 persen pada siklus 2 .
\end{abstract}

Kata kunci: Pembelajaan; Metode Inkuiri; Komunikasi Matematis.

\section{Pendahuluan}

Pembelajaran pada hakekatnya adalah proses interaksi antara peserta didik dengan lingkungannya, sehingga terjadi perubahan perilaku ke arah yang lebih baik (Mulyasa, 2002). Dalam pembelajaran, tugas guru yang paling utama adalah mengondisikan lingkungan agar menunjang terjadinya perubahan tingkah laku. Pembelajaran matematika menurut Russeffendi (1993) adalah suatu kegiatan belajar mengajar yang sengaja dilakukan untuk memperoleh pengetahuan dengan memanipulasi simbol-simbol dalam matematika sehingga menyebabkan perubahan tingkah laku.

Adapun tujuan pembelajaran matematika menurut Depdiknas (2007), yaitu agar siswa memiliki kemampuan: (1) memahami konsep matematika, menjelaskan keterkaitan antar konsep, dan mengaplikasikan konsep atau algoritma secara luwes, akurat, efisien, dan tepat dalam pemecahan masalah; (2) mengomunikasikan gagasan dengan simbol, tabel, diagram atau media lain untuk memperjelas masalah; (3) menggunakan penalaran pada pola dan sifat, melakukan manipulasi matematika dalam membuat generalisasi, menyusun bukti, atau menjelaskan gagasan dan pernyataan matematika; (4) memecahkan masalah yang meliputi kemampuan memahami masalah, merancang model matematika, menyelesaikan model dan menafsirkan solusi yang diperoleh; dan (5) memiliki sikap menghargai kegunaan matematika dalam kehidupan, yaitu memiliki rasa ingin tahu, perhatian, dan minat dalam mempelajari matematika, serta sikap ulet dan percaya diri dalam pemecahan masalah. Demikian pentingnya aspek komunikasi matematis dalam matematika ini, menurut NCTM (2000) disebutkan bahwa program-program pembelajaran dari pra TK hingga kelas 12 seharusnya memungkinkan semua siswa untuk: (1) mengatur dan menggabungkan pemikiran matematis mereka melalui komunikasi; (2) mengomunikasikan pemikiran matematis mereka secara koheren dan jelas kepada teman-teman, guru, dan orang lain; (3) menganalisis dan 
mengevaluasi pemikiran dan strategi-stategi matematis dari orang lain; dan (4) menggunakan bahasa matematika untuk mengekspresikan gagasan matematis secara tepat.

Menurut hasil pengamatan peneliti di SMP Negeri 2 Sampung, tampak bahwa pembelajaran di kelas VIII B masih secara konvensional. Siswa tampak menerima pelajaran dengan guru menyampaikan materi secara langsung kepada siswa dan setelah itu siswa mencatat apa yang telah diajarkan oleh gurunya tadi. Ketika peneliti menanyakan silabus dan rencana pelaksanaan pembelajaran (RPP) yang digunakan dalam pembelajaran matematika di SMP Negeri 2 Sampung tersebut memang komponennya sudah mengacu pada kurikulum 2013. Tetapi kenyataan yang terjadi di lapangan adalah pembelajaran konvensional dan cenderung siswa di drill. Setelah guru selesai menerangkan dan siswa telah mencatat apa yang diterangkan oleh guru, siswa diberikan tugas untuk mengerjakan soal-soal. Soal-soal tersebut cenderung serupa dan berulang-ulang.

Pada saat pengamatan, peneliti tidak jarang melakukan pembicaraan dengan guru matematika kelas VIII B SMP Negeri 2 Sampung, dan juga guru matematika kelas yang lain. Diperoleh keterangan bahwa pada dasarnya sebagian besar siswa sudah mempunyai minat yang cukup besar untuk belajar matematika. Namun, kemampuan siswa dalam berkomunikasi matematis masih tergolong rendah. Menurut guru tersebut, kurangnya kemampuan komunikasi matematis siswa itu dapat dilihat dari (1) Ketika dihadapkan pada suatu soal cerita, siswa tidak terbiasa menuliskan apa yang diketahui dan apa yang ditanyakan dari soal sebelum menyelesaikannya, sehingga siswa sering salah dalam menafsirkan maksud dari soal tersebut. (2) Siswa masih kurang paham terhadap suatu konsep matematika, hal ini tampak bahwa sebagian besar siswa masih kesulitan dalam menggunakan konsep himpunan dalam pemecahan masalah. (3) Kurangnya ketepatan siswa dalam menyebutkan simbol atau notasi matematika, hal ini tampak bahwa sebagian besar siswa masih belum bisa membedakan antara simbol untuk irisan himpunan dengan simbol untuk gabungan himpunan pada saat siswa kelas VII. (4) Adanya rasa enggan dan sikap raguragu siswa untuk sesekali mengungkapkan atau mengkomunikasikan gagasan-gagasan matematika baik melalui gambar, tabel, grafik, atau diagram. Dari informasi yang diperoleh, baik dari pengamatan yang dilakukan peneliti maupun dari wawancara kepada guru, maka dapat diketahui bahwa tingkat kemampuan komunikasi matematis siswa kelas VIII B SMP Negeri 2 Sampung masih relatif rendah. Tujuan penelitian ini adalah untuk mendeskripsikan penerapan metode inkuiri yang dapat meningkatkan komunikasi matematis siswa kelas VIII B SMP Negeri 2 Sampung.

Pembelajaran dengan penemuan (Inkuiri) merupakan satu komponen penting dalam pendekatan konstruktivisme yang telah memiliki sejarah panjang dalam inovasi atau pembaruan pendidikan. Dalam pembelajaran dengan penemuan atau inkuiri, siswa didorong untuk belajar sebagian besar melalui keterlibatan aktif mereka sendiri dengan konsepkonsep dan prinsip-prinsip, dan guru mendorong siswa untuk memiliki pengalaman dan melakukan percobaan yang memungkinkan mereka menemukan prinsip-prinsip untuk diri mereka sendiri. Piaget memberikan definisi pendekatan Inkuiry sebagai pendidikan yang mempersiapkan situasi bagi siswa untuk melakukan eksperimen sendiri. Mengajukan pertayaan-pertayaan dan mencari sendiri jawaban atas pertayaan yang mereka ajukan (Piaget dalam Sofan dan Iif, 2010). Metode inkuiri yang didefinisikan sebagai suatu rangkaian kegiatan belajar yang melibatkan secara maksimal seluruh kemampuan siswa untuk mencari 
dan menyelidiki secara sistematis, kritis, logis, dan analisis sehingga mereka dapat merumuskan sendiri penemuan dengan penuh percaya diri (Gellu dalam Sofan dan Lif, 2010).

Sedangkan menurut Goos (2004) pada proses pembelajaran yang terjadi di kelas, tindakan apa saja yang dilakukan guru dan murid dapat digambarkan sebagai berikut

\begin{tabular}{|c|c|c|}
\hline No & Tindakan Guru & Tindakan Murid \\
\hline 1 & $\begin{array}{l}\text { Mengkondisikan berpikir } \\
\text { dengan memberikan masalah }\end{array}$ & $\begin{array}{l}\text { Siswa mulai memberikan dugaan dan pembenaran } \\
\text { tanpa dorongan guru. Selama diskusi kelas, siswa } \\
\text { memulai argumentasi antar siswa tanpa mediasi } \\
\text { guru. }\end{array}$ \\
\hline 2 & $\begin{array}{l}\text { Guru mendorong siswa untuk } \\
\text { menemukan (inquiri). }\end{array}$ & $\begin{array}{l}\text { Siswa mulai menunjukkan dan memperbaiki } \\
\text { kesalahan mereka sendiri dan yang dibuat oleh } \\
\text { guru. } \\
\text { siswa spontan berkonsultasi yang ada pada buku } \\
\text { teks dan beberapa contoh untuk memperjelas } \\
\text { pemahaman mereka. }\end{array}$ \\
\hline 3 & Guru memberikan scaffolding. & $\begin{array}{l}\text { Siswa secara spontan memberikan klarifikasi, } \\
\text { elaborasi, kritik, dan pembenaran. } \\
\text { Siswa mengambil jawaban untuk menunjukkan } \\
\text { langkah-langkah strategis dan menghubungkan ke } \\
\text { pengetahuan sebelumnya. }\end{array}$ \\
\hline 4 & $\begin{array}{l}\text { Guru meminta mereka untuk } \\
\text { menguji gagasan melalui } \\
\text { kelompok. }\end{array}$ & $\begin{array}{l}\text { Siswa membentuk kelompok informal untuk } \\
\text { memantau kemajuan mereka, mencari umpan } \\
\text { balik pada ide-ide, dan menjelaskan ide satu } \\
\text { sama lain. }\end{array}$ \\
\hline 5 & $\begin{array}{l}\text { Guru mengembangkan } \\
\text { pengetahuan siswa untuk } \\
\text { berkomunikasi matematis }\end{array}$ & $\begin{array}{l}\text { Siswa mulai berdebat mengenai kesesuaian masing- } \\
\text { masing dan manfaatnya relatif berbeda dari yang } \\
\text { biasanya. }\end{array}$ \\
\hline
\end{tabular}

Menurut NCTM (2000) indikator komunikasi matematis dapat dilihat dari: (1) kemampuan mengekspresikan ide-ide matematis melalui lisan, tulisan, dan mendemonstrasikannya serta menggambarkannya secara visual, (2) kemampuan memahami, menginterpretasikan, dan mengevaluasi ide-ide matematis baik secara lisan, tulisan, maupun dalam bentuk visual lainnya, (3) kemampuan dalam menggunakan istilah-istilah, notasinotasi matematika dan strukturstrukturnya untuk menyajikan ide-ide, menggambarkan hubungan-hubungan dengan model-model situasi. Berdasarkan uraian di atas, indikator kemampuan komunikasi matematis yang akan digunakan dalam penelitian ini adalah (1) menjelaskan ide dan situasi secara tulisan, (2) menyatakan gambar atau diagram ke dalam ide-ide matematika, (3) menyatakan situasi ke dalam model matematika/ gambar.

\section{Metode}

Penelitian ini merupakan penelitian tindakan kelas yang menggunakan model KemmisTaggart dimana pelaksanaan tindakan dan observasi dilaksanakan dalam satu kegiatan (Wiriaatmadja, 2008). Pada penelitian ini, peneliti bertindak sebagai guru pengajar sekaligus sebagai pengamat dan fasilitator dengan subjek penelitian adalah siswa kelas VIIIB SMP Negeri 2 Sampung yang berjumlah 27 siswa. Pemilihan subjek penilitian ini didasarkan pada permasalahan yang muncul, yaitu kurangnya kemampuan komunikasi matematis yang merupakan hasil dari pengamatan non formal oleh peneliti. Pemilihan peneliti sebagai guru pengajar berdasarkan pertimbangan bahwa penelitilah yang lebih memahami desain penelitian yang akan dilaksanakan di kelas. 
Sumber data yang digunakan dalam penelitian ini adalah hasil observasi keterlaksanaan pembelajaran oleh guru dan siswa, tes yang dianalisis berdasarkan aspek kemampuan komunikasi matematis dan catatan lapangan. Data-data tersebut dikumpulkan dengan menggunakan teknik pengumpulan data berupa observasi, dokumentasi, tes dan catatan lapangan. Dokumentasi digunakan sebagai cara untuk mendapatkan bukti pembelajaran kususnya yang berhubungan dengan aktifitas siswa dalam mengembangkan kemampuan komunikasi matematis sedangkan catatan lapangan digunakan untuk mendapatkan data yang mungkin tidak di dapatkan dengan menggunakan lembar cara observasi, dokumentasi maupun tes. Tes dilaksanakan di setiap akhir siklus. Tes berupa soal uraian yang terdiri dari 5 soal.

Prosedur penelitian tindakan kelas ini, menggunakan model Kemmis dan Mc Taggart. Menurut Kemmis dan Mc Taggart penelitian tindakan dapat dipandang sebagai suatu siklus spiral dari penyusunan perencanaan, pelaksanaan tindakan, pengamatan (observasi), dan refleksi. Selanjutnya mungkin diikuti dengan siklus spiral berikutnya.

Adapun tahap perencanaan meliputi kegiatan berikut: (1) Membuat skenario pembelajaran yang berisikan langkah-langkah kegiatan dalam pembelajaran. (2) Mempersiapkan sarana pembelajaran yang mendukung misalnya saja membuat lembar observasi untuk melihat kondisi belajar mengajar di kelas ketika metode inkuiri diaplikasikan. Selain itu juga membuat sarana pembelajaran yang lain seperti lembar kegiatan siswa (LKS). (3) Mempersiapkan instrumen penelitian, misalnya saja untuk pengumpulan data tentang proses, kegiatan, dan hasil pembelajaran. Selain itu juga dapat mendesain alat evaluasi untuk melihat apakah konsep matematika yang diajarkan telah dikuasai oleh siswa. (4) Melakukan simulasi pelaksanaan tindakan dan menguji keterlaksanaannya di lapangan.

Pelaksanaan tindakan, kegiatan yang dilaksanakan dalam tahap ini adalah melaksanakan skenario pembelajaran sesuai dengan rencana pelaksanaan pembelajaran yang telah dibuat. Pada tahap pelaksanaan ini dilakukan tahap-tahap pembelajaran Inkuiri. Pelaksanaan tindakan dilaksanakan di SMPN 2 Sampung dengan subyek siswa kelas VIIIB.

Observasi/evaluasi, pada tahap ini dilaksanakan observasi terhadap pelaksanaan tindakan serta melakukan evaluasi. Observasi dilakukan oleh observer yang terdiri dari 2 orang. Satu orang mahasiswa dan satu orang lagi guru matematika SMPN 2 Sampung. Sedangkan evaluasi dilakukan oleh peneliti.

Refleksi hasil yang diperoleh dalam tahap observasi/evaluasi dikumpulkan serta dianalisis dalam tahap ini. Peneliti menuliskan temuan-temuan serta kelemahan-kelemahan pada siklus pertama. Kelemahan-kelemahan/ kekurangan-kekurangan yang terjadi pada setiap siklus akan diperbaiki pada siklus berikutnya.

\section{Hasil dan Pembahasan}

\subsection{Hasil}

Penelitian dilaksanakan dalam 2 siklus, masing-masing siklus terdiri 2 pertemuan. Langkah-langkah pembelajaran yang dipakai adalah langkah-langkah inkuiri menurut Goos yaitu (1) mengondisikan berpikir matematis dengan memberikan masalah, (2) mendorong siswa untuk menemukan (inquiri), (3) memberikan Scaffolding, (4) menguji 
gagasan melalui kelompok, (5) mengembangkan pengetahuan siswa untuk berkomunikasi matematis.

Pada tahapan mengondisikan berpikir matematis dengan memberikan masalah. Tindakan yang dilakukan adalah siswa mulai memberikan dugaan dan pembenaran tanpa dorongan guru. Selama diskusi kelas, siswa memulai argumentasi antar siswa tanpa mediasi guru. Pada saat siswa diberikan masalah oleh guru, dalam kelompoknya siswa berdiskusi untuk memahami masalah tersebut. Siswa saling berargumentasi dan memberikan dugaan untuk menyeleseikan masalah tersebut. pada tahapan ini sebenarnya sudah berjalan dengan baik, namun pada siklus 1 masih ada kelompok yang yang bertanya pada guru mengenai masalah 1 tanpa mendiskusikannya terlebih dahulu bersama kelompoknya, padahal seharusnya pada tindakan ini siswa harus mendiskusikan bersama kelompoknya untuk memahami dan memberikan dugaan untuk menyelesaikan masalah 1 tersebut. Jika memang dalam berdiskusi kelompok pemahaman mereka sudah buntu barulah mereka dapat berkonsultasi pada buku atau pada guru. Hal ini tergolong dalam langkah pembelajaran Inkuiri yang kedua yaitu tahapan mendorong siswa untuk menemukan (inquiri).

Pada tahapan mendorong siswa untuk menemukan (inquiri), siswa mulai menunjukkan dan memperbaiki kesalahan mereka sendiri dan yang dibuat oleh guru. siswa spontan berkonsultasi yang ada pada buku teks dan beberapa contoh untuk memperjelas pemahaman mereka. Pada tahapan ini setelah siswa berdiskusi dengan kelompoknya, siswa berkonsultasi kepada guru untuk meyakinkan bahwa pemahaman yang mereka peroleh sudah benar. Jika masih belum benar, siswa memperbaiki kesalahannya. Pada tahapan ini siswa diminta untuk menemukan Teorema Pythagoras. Siswa diarahkan untuk menemukan Teorema Pythagoras dari 4 buah segitiga yang disusun menjadi sebuah persegi yang ada di masalah 1 LKS 1 siklus pertama.

Tahapan pembelajaran Inkuiri yang berikutnya adalah memberikan Scaffolding. Siswa secara spontan memberikan klarifikasi, elaborasi, kritik, dan pembenaran. Siswa mengambil jawaban untuk menunjukkan langkah-langkah strategis dan menghubungkan ke pengetahuan sebelumnya. Scaffolding yang diberikan oleh guru adalah langkah-langkah kegiatan yang harus dilakukan siswa dalam LKS. Dengan adanya langkah-langkah yang jelas siswa akan mudah menentukan apa yang harus dia lakukan. Pada siklus pertama, guru memberikan langkah-langkah membuktikan bahwa suatu segiempat adalah persegi yang nantinya dari persegi itu digunakan untuk menemukan Teorema Pythagoras, namun ternyata masih ada siswa yang kurang memahaminya. Hal ini dikarenakan siswa tersebut lupa pada pengetahuan sebelumnya mengenai segitiga yaitu bahwa jumlah sudut ketiga segitiga adalah $180^{\circ}$.

Tahapan selanjutnya pada pembelajaran Inkuiri adalah menguji gagasan melalui kelompok. Siswa membentuk kelompok informal untuk memantau kemajuan mereka, mencari umpan balik pada ide-ide, dan menjelaskan ide satu sama lain. Langkah ini dilakukan pada awal proses pembelajaran sampai akhir pembelajaran. Semua langkah-langkah inkuiri yang ada dilakukan dalam kelompok. Salah satu contoh tindakan yang dilakukan siswa pada tindakan ini adalah pada saat mereka memilih tiga persegi untuk disusun menjadi sebuah 
segitiga siku-siku. Pada kegiatan tersebut siswa saling mengungkapkan ide satu sama lain hingga ada siswa yang dapat menemukan bahwa persegi yang dipilih agar dapat terbentuk segitiga siku-siku sisi-sisinya harus memenuhi persamaan teorema pythagoras.

Tahapan pembelajaran inkuiri yang terakhir adalah mengembangkan pengetahuan siswa untuk berkomunikasi matematis. Siswa mulai berdebat mengenai kesesuaian masing-masing dan manfaatnya relatif berbeda dari yang biasanya. Pada langkah ini kegiatan yang dilakukan adalah setelah siswa selesai berkelompok menyelesaikan masalah, lalu diminta salah satu kelompok untuk maju mempresentasikan hasil pekerjaannya ke depan kelas. Dari kegiatan ini kelompok lain akan menanggapi jika ada hasil pekerjaan yang tidak sesuai. Dengan melakukan tahapan-tahapan pembelajaran inkuiri pada siklus pertama siswa dapat menemukan persamaan teorema Pythagoras yaitu pada segitiga siku-siku berlaku sisi miring kuadrat sama dengan jumlah kuadrat sisi-sisi yang lain, atau menuliskannya $a^{2}+b^{2}=c^{2}$ dimana $c$ adalah sisi miring, $a$ dan $b$ adalah sisi-sisi yang lain.

Beberapa hal yang ditemukan selama proses pembelajaran di siklus 1 ini adalah sebagai berikut. (1) Pembelajaran berlangsung cukup baik namun aktifitas diskusi dari siswa masih kurang. Kemampuan komunikasi matematis siswa untuk beberapa indikator, diantaranya kemampuan untuk mengubah permasalahan dalam bentuk matematika, kemampuan menggali informasi, kemampuan menyampaikan ide penyelesaian masalah tergolong cukup baik namun perlu ditingkatkan kembali. (2) Pada pertemuan pertama masih kurang efektif karena banyak siswa yang tidak masuk sekolah dikarenakan pada hari sebelumnya diadakan perkemahan jadi banyak siswa yang kelelahan. (3) Pertemuan ke-2 yang seharusnya dilakukan pada hari sabtu mundur menjadi hari senin karena pada hari sabtu ada kegiatan sekolah, hal ini membuat waktu pelaksanaan penelitian menjadi mundur.

Tindakan pada siklus pertama masih belum berhasil sehingga tindakan akan dilanjutkan pada siklus kedua. Kegiatan yang akan dilaksanakan pada siklus dua adalah kegiatan perencanaan, tindakan dan observasi, refleksi dan evaluasi. Kegiatan perencanaan pada siklus dua didasarkan pada hasil refleksi dan evaluasi pada siklus pertama. Kegiatan tindakan dan observasi untuk melaksanakan tindakan sesuai dengan perencanaan yang telah dilakukan dan melakukan observasi oleh observer penelitian.

Hasil observasi keterlaksanaan pembelajaran oleh siswa pada siklus 1 dilakukan oleh 2 orang observer. Diperoleh hasil presentase rata-rata pelaksanaan pembelajaran oleh siswa sebesar $77,12 \%$ atau pada kategori baik. Sedangkan keterlaksanaan pembelajaran guru, diperoleh skor rata-rata total 79,16\% berada dalam kategori Baik. Sedangkan berdasarkan hasil dari tes 1 siklus 1 dapat diketahui bahwa kemampuan komunikasi matematis siswa rata-rata berada dalam kategori cukup dengan rata-rata skor 66,66\%. 9 siswa pada kategori cukup, sedangkan 16 siswa pada kategori baik.

Hasil observasi menunjukkan pelaksanaan pembelajaran oleh siswa pada siklus 2 mendapat persentase rata-rata total sebesar $84,10 \%$ atau pada kategori sangat baik. Sedangkan pelaksanaan pembelajaran oleh guru mendapat skor rata-rata total 93,05\% atau dalam kategori sangat baik. Sedangkan berdasarkan hasil tes kemampuan komunikasi matematis siswa dapat diketahui bahwa kemampuan komunikasi matematis siswa rata-rata 
berada dalam kategori baik dengan rata-rata skor 77,77\%. 10 siswa pada kategori sangat baik, 11 siswa pada kategori baik, sedangkan 6 siswa pada kategori cukup. Berdasarkan hasil evaluasi dan refleksi yang telah dilakukan maka peneliti dapat menyatakan bahwa semua indikator keberhasilan yang sudah ditetapkan telah terpenuhi. Dengan demikian, penelitian dihentikan pada siklus kedua.

\subsection{Pembahasan}

Penelitian ini dilaksanakan dalam dua siklus, karena indikator keberhasilanya sudah tercapai pada siklus kedua. Siklus pertama dilakukan 2 kali pertemuan dengan melaksanakan satu kali tindakan. Hal ini dilakukan karena peneliti masih ingin mengetahui keefektifan waktu pengerjaan oleh siswa dan tingkat pemahaman siswa pada materi. Dari hasil siklus satu ternyata ditemukan fakta bahwa waktu yang digunakan memang efektif dan sesuai dengan yang direncanakan, tetapi pemahaman materi oleh siswa belum terlalu baik. Hal ini disebabkan karena pemantapan materi tidak dilaksanakan langsung dalam satu kali pertemuan melainkan ada pemisahan sehingga pemahaman siswa juga terpisah.

Pada awal pembelajaran, siswa diberikan kesempatan untuk duduk berkelompok sesuai dengan kelompok yang telah disusun oleh guru dengan masing-masing anggota kelompok sebanyak 5-6 siswa. Setelah tahap pengelompokan selesai, siswa diberikan lembar kerja, selanjutnya, siswa bersama-sama dengan kelompoknya memperhatikan masalah 1 yang ada pada LKS. Ini adalah tahapan metode inkuiri yaitu mengondisikan berfikir dan memberikan masalah. Selanjutnya siswa memperhatikan dan memahami cara-cara menunjukkan bahwa suatu segiempat adalah persegi. Cara-cara yang harus dilakukan tersebut sudah terdapat di LKS, ini adalah tahapan metode inkuiri yaitu guru memberikan scaffolding. Setelah siswa menunjukkan bahwa segiempat yang terbentuk ternyata adalah persegi selanjutnya dengan persegi dan segitiga-segitiga yang ada siswa akan berdiskusi dengan kelompoknya untuk menemukan Teorema Pythagoras. Tahapan ini adalah mendorong siswa untuk menemukan (Inquiri). Setelah pekerjaan siswa selesai untuk menemukan Teorema Pythagoras, selanjutnya siswa menuliskan di depan kelas untuk menyampaikan kepada kelompok lain. Ini adalah kegiatan yang dilakukan pada pertemuan pertama siklus 1, selanjutnya pada pertemuan ke dua, komponen metode inkuiri yang dilakukan selama proses pembelajaran adalah guru memberikan scaffolding, menguji gagasan melalui kelompok, dan mengembangkan kemampuan siswa untuk berkomunikasi matematis.

Pada penelitian yang telah dilakukan ditemukan beberapa siswa yang tidak mampu menyelesaikan permasalahan karena mereka lupa dengan konsep sebelumnya. Hal ini menunjukkan bahwa kegiatan apersepsi di awal pembelajaran penting untuk dilakukan agar siswa dapat mengingat kembali materi-materi sebelumnya untuk digunakan pada penyelesaian masalah di pembelajaran yang sekarang. Selain itu, dengan melalui kegiatan apersepsi siswa dapat diajak untuk menghubungkan materi-materi yang telah dipelajari dan yang akan dipelajari.

Hasil tindakan pada siklus 1 belum terlihat, hal ini ditunjukkan oleh hasil observasi yang berada kategori cukup. Siswa masih terlihat ragu-ragu dalam menyampaikan pendapatnya saat berdiskusi maupun saat kegiatan presentasi. Siswa juga cenderung lebih meminta bantuan kepada guru langsung jika dibandingkan dengan anggota kelompoknya. Untuk mengatasi hal ini, dalam membarikan bantuan, guru bukan langsung memberikan jawaban kepada siswa yang bertanya, malainkan memberikan pertanyaan balikan kepada 
semua anggota kelompok sehingga masing-masing siswa dapat menyusun sendiri jawaban dari pertanyaan yang diberikan.

Pada beberapa aspek tertentu dalam komunikasi matematis menunjukkan adanya penurunan skor baik dilihat dari observasi maupun tes. Salah salah satu faktor penyebabnya adalah adanya perbedaan tingkat kesulitan materi. Materi yang lebih sulit dan membutuhkan pemahaman terhadap materi sebelumnya akan membuat siswa juga lebih sulit dalam mengungkapkan ide dan menyelesaikan masalah. Namun disisi lain, adanya tingkat kesulitan materi yang berbeda juga membuat siswa justru lebih aktif dalam kegiatan berkelompok. Siswa saling bertanya dan memberikan sanggahan jika terdapat perbedaan pendapat.

Hasil penerapan pembelajaran dengan metode Inkuiri menunjukkan bahwa dengan metode ini dapat meningkatkan kemampuan komunikasi matematis siswa. Dari hasil tes pada siklus 1 menunjukkan bahwa 18 siswa berada pada kategori minimal baik atau 66,6\% siswa pada kategori minimal baik. Oleh karena itu penelitian dilanjutkan pada siklus ke dua. Pada siklus 2 berdasarkan hasil tes, kemampuan komunikasi siswa berada pada kategori baik yaitu 21 siswa berada pada kategori minimal baik, atau sebesar $77,7 \%$ siswa pada kategori minimal baik.

Dengan demikian, secara klasikal kemampuan komunikasi matematis siswa berdasarkan hasil tes meningkat dari $66,6 \%$ pada siklus 1 menjadi $77,7 \%$ pada siklus 2 . Dengan demikian, pembelajaran dengan metode inkuiri pada penelitian ini menunjukkan suatu metode yang cocok untuk mengambangkan kemampuan komunikasi siswa. Meskipun pelaksanaan pembelajaran telah sesuai dengan tahapan metode inkuiri dan hasil yang didapatkan memenuhi kriteria namun dalam pelaksanaannya masih ditemukan beberapa kendala. Kendala tersebut ditemukan selama kegiatan penelitian berlangsung.

\section{Simpulan}

\subsection{Kesimpulan}

Pembelajaran dengan menggunakan metode inkuiri dapat meningkatkan kemampuan komunikasi matematis siswa kelas VIII B SMP Negeri 2 Sampung. Model pembelajaran ini diterapkan dalam 5 tahap, yaitu mengondisikan berpikir matematis dengan memberikan masalah, mendorong siswa untuk menemukan (inquiri), memberikan Scaffolding, menguji gagasan melalui kelompok, dan mengembangkan pengetahuan siswa untuk berkomunikasi matematis.

\subsection{Saran}

Berdasarkan hasil penelitian ini, pembelajaran dengan metode inkuiri dapat digunakan sebagai salah satu alternatif untuk meningkatkan kemampuan komunikasi matematis siswa. Sebagai tindak lanjut untuk penelitian selanjutnya, peneliti memberikan beberapa saran sebagai berikut. (1) Mengembangkan metode pembelajaran inkuiri untuk meningkatkan kemampuan komunikasi matematis pada aspek-aspek yang lain. (2) Bagi peneliti berikutnya dan guru diharapkan dapat kreatif untuk mengembangkan pembelajaran dengan metode inkuiri dalam proses pembelajaran dengan penggunaan media-media yang dapat mendukung pembelajaran, misalnya media interaktif komputer atau media konkret yang relevan. (3) Peneliti-peneliti berikutnya selalu memperhatikan alokasi waktu. 


\section{Jurnal MIPA dan Pembelajarannya, 1(12), 2021, 942-950}

\section{Daftar Rujukan}

Amri, S., \& Ahmadi, I. K. (2010). Konstruksi pengembangan pembelajaran. Jakarta: Prestasi Pustaka.

Depdiknas. (2007). Standar Isi. http://www.bsnpindonesia.org/files/Standar Isi.pdf. [15 Desember 2013]

Goos, M. (2004). Learning mathematics in a classroom community of inquiry. Journal for research in mathematics education, 35(4), 258-291.

Mulyasa, E. (2002). Manajemen berbasis sekolah, Bandung, Penerbit PT. Remaja Rosdakarya.

Principles, N. C. T. M. (2000). Standards for school mathematics. Virginia: The National Council of Teachers of Mathematics.

Ruseffendi, E. T., Karso, P., \& N \& Kusumah, J. S. (1993). Pendidikan matematika 3 modul 1-5. Jakarta: Universitas Terbuka.

Wiriaatmadja, R. (2008). Metode penelitian tindakan kelas. PT Remaja Rosdakarya. 